\title{
Combined Effect of Coffee Consumption and Cigarette Smoking on Serum Levels of Vitamin B I2, Folic Acid, and Lipid Profile in Young Male: A Cross-Sectional Study [Corrigendum]
}

\author{
Abu-Taha M, Dagash R, Mohammad BA, et al. Int J Gen \\ Med. 2019;12:421-432.
}

Upon reviewing the published article, the authors noticed an error that they had overlooked while completing their revisions. The affiliation of Beisan A Mohammad is incorrect. On page 421 the current author details read:

May Abu-Taha ${ }^{1}$

Rajaa Dagash ${ }^{1}$

Beisan A Mohammad ${ }^{2}$

Iman Basheiti ${ }^{1}$

Mahmoud S Abu-Samak ${ }^{1}$

${ }^{1}$ Department of Clinical Pharmacy and Therapeutics, Faculty of Pharmacy, Applied Science Private University,
Amman, Jordan; ${ }^{2}$ PharmD Department, Fakeeh College for Medical Sciences, Jeddah, Kingdom of Saudi Arabia

And should be replaced with:

May Abu-Taha ${ }^{1}$

Rajaa Dagash ${ }^{1}$

Beisan A Mohammad ${ }^{2}$

Iman Basheiti ${ }^{1}$

Mahmoud S Abu-Samak ${ }^{1}$

${ }^{1}$ Department of Clinical Pharmacy and Therapeutics, Faculty of Pharmacy, Applied Science Private University, Amman, Jordan; ${ }^{2}$ Pharmaceutical Sciences Department, Fakeeh College for Medical Sciences, Jeddah, Kingdom of Saudi Arabia

\section{Publish your work in this journal}

The International Journal of General Medicine is an international, peer-reviewed open-access journal that focuses on general and internal medicine, pathogenesis, epidemiology, diagnosis, monitoring and treatment protocols. The journal is characterized by the rapid reporting of reviews, original research and clinical studies across all disease areas. The manuscript management system is completely online and includes a very quick and fair peer-review system, which is all easy to use. Visit http://www.dovepress.com/ testimonials.php to read real quotes from published authors. 